\title{
Effect of cumin essential oil usage on fermentation quality, aerobic stability and in vitro digetibility of alfalfa silage
}

\author{
Aslı Turan ${ }^{1}$ and Sibel Soycan Önenç ${ }^{1, *}$
}

* Corresponding Author: Sibel Soycan Önenç Tel: +90-282-250-21-86, Fax: +90-282-250-99-29,

E-mail: ssonenc@nku.edu.tr

'Department of Animal Science, Faculty of Agriculture, University of Namık Kemal, Tekirdağ 59030, Turkey

ORCID

Asll Turan

https://orcid.org/0000-0001-5118-9155

Sibel Soycan Önenç

https://orcid.org/0000-0001-9452-4435

Submitted Nov 15, 2017; Revised Jan 2, 2018; Accepted Feb 8, 2018
Objective: This study was carried out to determine the effects of cumin essential oil on the silage fermentation, aerobic stability and in vitro digestibility of alfalfa silages.

Methods: Alfalfa was harvested at early bloom (5th cutting) stage in October and wilted for about 3 hours. The research was carried out at three groups which were the control group where no additive control was done (CON), cumin essential oil (CMN3) with $300 \mathrm{mg} / \mathrm{kg}$ and CMN5 with $500 \mathrm{mg} / \mathrm{kg}$ cumin essential oil addition. Alfalfa was ensiled in plastic bags. The packages were stored at $8^{\circ} \mathrm{C} \pm 2^{\circ} \mathrm{C}$ under laboratory conditions. All groups were sampled for physical, chemical and microbiological analysis 120th day after ensiling. At the end of the ensiling period, all silages were subjected to an aerobic stability test for 7 days. In addition, enzimatic solubility of organic matter (ESOM), metabolizable energy (ME), and relative feed value (RFV) of these silages were determined.

Results: $\mathrm{pH}$ level decreased in the cumin groups compared to $\mathrm{CON}(\mathrm{p}<0.05)$, thus inhibiting proteolytic enzymes from breaking down proteins into ammonia. In addition, it increased ESOM amount, and concordantly provided an increase of ME contents. Similarly, dry matter intake and RFV ratio increased. After opening the silage, it kept its aerobic stability for three days.

Conclusion: Cumin essential oil improved fermentation, and affected chemical and microbiological characteristics of silages. Especially the addition of $300 \mathrm{mg} / \mathrm{kg}$ cumin provided cell wall fractionation through stimulating the activities of enzymes responsible. It also increased the number and activity of lactic acid bacteria (LAB) through providing a development of LAB.

Keywords: Alfalfa; Silage; Cumin; Essential Oil; In vitro Digestibility

\section{INTRODUCTION}

Roughage has a significant importance in ruminant feeding in both nutrition physiology and enterprise economy [1]. Alfalfa (Medicago sativa) is one of the most important forage plants given to livestock as hay. However, a significant amount of nutrient loss occurs due to the mechanical treatments during drying and storage process [1]. Recently, especially in regions with copious amount of precipitation, where there is not enough opportunity to dry late harvested alfalfa, it is usually processed as silage. Alfalfa as green forage for silage is classified as difficult to silage due to its high protein level and buffer capacity and its low watersoluble carbohydrate (WSC) ingredients. Therefore, it becomes compulsory to use additives in order to silage forage such as alfalfa [2].

Due to their being effective in inhibiting development and killing microorganisms, antibiotics are used as additives in silage processing [2]. However, the prohibiton of antibiotics to be used as additives has increased interest in natural products from aromatic plants and products of these plants to be used in food, animal nutrition. Although the microbial effect 
of plant extracts is recognized, there is limited research about these plants to be used as silage additive $[3,4,5]$.

The aim of this study is to determine the effects of cumin essential oil as an additive on the fermentation quality, aerobic stability, in vitro metabolic energy components and relative feed value.

\section{MATERIALS AND METHODS}

Experimental treatments and silage preparation

Alfalfa was withered for three hours after harvest at the beginning of blooming period in October (5th cutting). After withering process, it was chopped in the silage cutter at approximately 1.5 to $2.0 \mathrm{~cm}$ length, and cumin essential oil was added. The research was carried out at three groups which were the control group where no additive $\mathrm{CON}$ was done, CMN3 with $300 \mathrm{mg} / \mathrm{kg}$ and CMN5 with $500 \mathrm{mg} / \mathrm{kg}$ cumin essential oil addition. Cumin essential oil (Cuminum cyminum L.) used in this research was obtained from Ege Lokman Plant Botanic Firm. The components of essential oil obtained through water vapor distillation are given in Table 1.

The level of cumin essential oil was determined according to previous studies. For every group, $6 \mathrm{~kg}$ withered alfalfa was spread on the ground separately and was sprayed with uniform cumin essential oil ( $300 \mathrm{mg} / \mathrm{kg}$ and $500 \mathrm{mg} / \mathrm{kg}$ ). Approximately $2 \mathrm{~kg}$ of sample was put into plastic bags and air was vacuumed out of the bags. These bags were covered 8 to 10 times with stretch wrap and finally were sealed with adhesive tape. Nine packages were prepared in total as triplicate of silage for each group and were kept in a closed storage $\left(8^{\circ} \mathrm{C} \pm 2^{\circ} \mathrm{C}\right)$ for 120 for fermentation.

\section{Physical analysis}

At the end of ensilage period silages were spread on a flat surface and were observed by three different observers for colour, odour, and structure. Physical evaluation was carried out through the average of scores given by the three observers. Flieg's Score was calculated through the determination of dry matter (DM) and $\mathrm{pH}$ values of silages [2].

Table 1. The chemical composition of cumin essential oil (\%)

\begin{tabular}{lc}
\hline Compouns & Value \\
\hline Cuminaldehyde & 44.47 \\
Carvacrol & 12.12 \\
Para Cymen & 8.82 \\
Safranal & 6.57 \\
Gamma Terpinen & 5.64 \\
Beta-pinen & 4.93 \\
(-) Alpha Cedren & 4.48 \\
Others & 9.86 \\
Unknown & 3.11 \\
Total & 100 \\
\hline
\end{tabular}

Flieg's score $=220+(2 \times \%$ DM-15) $-40 \times \mathrm{pH}$

\section{Chemical analysis}

The gas chromatography-mass spectrometry analyses of the cumin essential oil were performed at the Ege University Center R\&D and Pharmacokinetic Applications-Environmental \& Food Analysis Laboratories-Food Control Laboratory (Bornova, Izmir, Turkey).

$\mathrm{pH}$ value was measured via a digital $\mathrm{pH}$ meter, lactic acid (LA) was measured through LA spectrophotometric method [6]. Buffer capacity $(\mathrm{Bc})$ in fresh material was determined according to Playne and McDonald [7]. NH3-N and WSC of silages were stated through methods revealed in Anonymous [8]. Seven-days aerobic stability test was carried out on samples developed by Ashbell et al [9].

The DM content was determineted after being oven dried at $60^{\circ} \mathrm{C}$ for $72 \mathrm{~h}$. The dried samples were ground through a 1 $\mathrm{mm}$ screen for chemical analysis. The $\mathrm{DM}$ was determined by drying the samples at $105^{\circ} \mathrm{C}$ for $16 \mathrm{~h}$. Organic matter (OM), crude protein $(\mathrm{CP})$, and ether extract (EE) contents of feed samples were determined by AOAC [10].

Fibre that forms the cell walls of forages and is not dissolved in neutral detergent fiber (NDF), not dissolved in acid detergent fiber (ADF) and contents of lignin not dissolved in acid detergent were determined according to methods stated by Van Soest et al [11]. Hemicellulose and cellulose were determined through calculation [11]. Enzimatic solubility of organic matter (ESOM) was determined with the procedure reported by Nauman and Bassler [12]. In the technique, pre-treatment with pepsin-hydrochloric acid solution, followed treatment by cellulase (Onozuka R 10 from Trichoderma viride, Merck, Darmstadt, Germany) .

\section{Microbiologic analysis}

For microbial enumeration 9 replicete used for each trial groups. This purpose, lactic acid bacteria (LAB), yeast and mould were determined according to Seale et al [13]. In the enumeration of LAB, plates of Rogosa agar (Oxoid CM627) were used and the yeast was on spread plate malt extract agar acidified with LA to $\mathrm{pH}$ 4.0. The plates were incubated for 3 days at $30^{\circ} \mathrm{C}$. The $\mathrm{LAB}$, mould and yeast numbers of the silages were converted into logarithmic colony form unit (cfu/g).

\section{Metabolizable energy and relative forage value estimating}

In vitro metabolizable energy (ME) contents in silages were calculated through the use of crude nutrition components (CNC), NDF, ADF, acid detergent lignin (ADL), and ESOM determined as a result of chemical analysis according to the equation given below: 


$$
\text { i) } \begin{aligned}
& \mathrm{ME}_{\mathrm{ESOM}}(\mathrm{MJ} / \mathrm{kg} \mathrm{DM}) \\
&=0.54+0.001987 \mathrm{CP}^{*}+0.01537 \mathrm{ESOM}^{\star}+0.000706 \mathrm{EE}^{\star} \\
& \times \mathrm{EE}^{*}-0.00001262 \mathrm{ESOM}^{*} \times \mathrm{CA}^{\star}-0.00003517 \mathrm{ESOM}^{\star} \\
& \times \mathrm{CP}{ }^{*} \\
&(\mathrm{CP}, \mathrm{EE}, \mathrm{CA} \text { g } / \mathrm{kg} ; \mathrm{ESOM} \text { in } \mathrm{g} / \mathrm{kg} \mathrm{DM})
\end{aligned}
$$

ii) $\mathrm{ME}_{\mathrm{CNC}}(\mathrm{kcal} / \mathrm{kg} \mathrm{OM})$

$$
\begin{aligned}
& =3.260+\left(0.455 \times \mathrm{CP}^{*}+3.517 \times \mathrm{EE}^{*}\right)-4.037 \times \mathrm{CF}^{*} \\
& \left({ }^{*} \text { in } \mathrm{OM} \mathrm{g} / \mathrm{kg}\right)
\end{aligned}
$$

iii) $\mathrm{ME}_{\mathrm{NDF}}(\mathrm{kcal} / \mathrm{kg} \mathrm{DM})=3381.9-19.98 \times \mathrm{NDF}^{*}$

iv) $\mathrm{ME}_{\mathrm{ADF}}(\mathrm{MJ} / \mathrm{kg} \mathrm{DM})=14.70-0.150 \times \mathrm{ADF}^{*}$

v) $\mathrm{ME}_{\mathrm{ADL}}(\mathrm{kcal} / \mathrm{kg} \mathrm{DM})=2,764.4-102.73 \times \mathrm{ADL}^{*} \quad$ [16]

${ }^{\star} \mathrm{NDF}, \mathrm{ADF}$, and $\mathrm{ADL}$ in $\%, \mathrm{ME}$ contents were translated into kilocalories.

Equations developed by Van Dyke and Anderson [18] and given below were used in the determination of relative forage value. Firstly digestible dry matter (DDM), secondly dry matter intake (DMI) was estimated and finally relative feed value (RFV) was predicted.

$$
\begin{aligned}
& \mathrm{DDM}(\% \text { of } \mathrm{DM})=88.9-(0.779 \times \% \mathrm{ADF}) \\
& \mathrm{DMI}(\text { as a } \% \text { body weight })=120 / \% \mathrm{NDF} \\
& \mathrm{RFV}=\mathrm{DDM} \times \mathrm{DMI} \times 0.775
\end{aligned}
$$

\section{Statistical analyses}

All data were analyzed using the general linear model procedure of SPSS ver.15 (SPSS Inc., Chicago, IL, USA). Differences among treatments were compared with Duncan's test [19].

\section{RESULTS}

The silage in CON, CMN3, and CNM5 groups was browngreen in colour, slightly acidic and pleasantly aromatic in odour, stem and leaf unity was not deteriorated; whereas according to physical evaluation in all silages the quality level was found to be satisfactory with 13 points as given in Table 2. According to Flieg's score evaluations, it was determined that the quality level of groups with cumin essential oil addition were better in comparison to control group.

Chemical composition of wilting alfalfa and after ensiled alfalfa is given in Table 3. Cumin essential oil addition prevented protein fractionation (proteolysis), especially in CNM3 group wherer $\mathrm{CP}$ amount was found to be $24.52 \%(\mathrm{p}<0.05)$. In this period, also the determination of $\mathrm{NH}_{3}-\mathrm{N}$ being 14.50 $\mathrm{g} / \mathrm{kg} \mathrm{TN}(\mathrm{p}<0.05)$ at the lowest level supports this condition. Adding CNM3 into the silages decreased crude fiber (CF), $\mathrm{NDF}, \mathrm{ADF}$, and ADL levels compared to CON ( $\mathrm{p}<0.05)$, but CNM5 increased CF and ADF levels compared to CON ( $p<$ 0.05).

The addition of cumin essential oil had no affect on dry matter (Table 4). pH level of silages decreased significantly in comparison to the control group $(\mathrm{p}<0.05)$. While cumin essential oil was found effective in the prevention of weitgh loss (WL), it was determined that WL at CMN3 and CMN5 groups was $1.46 \%, 1.33 \%$, and $1.25 \%(\mathrm{p}<0.05)$ respectively. However, LA levels in both groups increased compared to CON group

\begin{tabular}{|c|c|c|c|c|c|c|c|c|c|c|c|}
\hline Treatments ${ }^{1)}$ & OM & $\mathrm{CP}$ & $\mathrm{EE}$ & $\mathrm{CF}$ & NFE & CA & NDF & ADF & $A D L$ & Hemicellulose & Cellulose \\
\hline WA & 90.28 & 23.90 & 2.86 & 20.21 & 43.31 & 9.72 & 38.41 & 29.01 & 8.82 & 9.4 & 20.19 \\
\hline CON & $84.41 \pm 0.06^{b}$ & $23.06 \pm 0.04^{c}$ & $3.35 \pm 0.01^{\mathrm{ab}}$ & $20.99 \pm 0.19^{b}$ & $35.55 \pm 0.01^{c}$ & $15.59 \pm 0.06^{a}$ & $33.15 \pm 0.09^{a}$ & $26.18 \pm 0.10^{b}$ & $9.51 \pm 0.13^{\mathrm{a}}$ & $6.97 \pm 0.15^{\mathrm{a}}$ & $16.68 \pm 0.15^{b}$ \\
\hline CMN3 & $89.86 \pm 0.01^{a}$ & $24.52 \pm 0.07^{\mathrm{a}}$ & $3.18 \pm 0.08^{b}$ & $18.65 \pm 0.10^{c}$ & $44.46 \pm 0.08^{a}$ & $10.14 \pm 0.02^{b}$ & $28.22 \pm 0.12^{c}$ & $21.83 \pm 0.05^{c}$ & $6.29 \pm 0.23^{c}$ & $6.38 \pm 0.16^{b}$ & $15.55 \pm 0.28^{c}$ \\
\hline CMN5 & $89.89 \pm 0.04^{a}$ & $23.57 \pm 0.07^{b}$ & $3.47 \pm 0.01^{\mathrm{a}}$ & $21.71 \pm 0.02^{\mathrm{a}}$ & $41.65 \pm 0.05^{b}$ & $10.11 \pm 0.04^{b}$ & $31.22 \pm 0.12^{b}$ & $27.48 \pm 0.22^{a}$ & $8.62 \pm 0.23^{b}$ & $3.74 \pm 0.10^{c}$ & $18.86 \pm 0.43^{\mathrm{a}}$ \\
\hline$p$ & 0.001 & 0.001 & 0.001 & 0.001 & 0.001 & 0.001 & 0.001 & 0.001 & 0.001 & 0.001 & 0.001 \\
\hline
\end{tabular}
$(\mathrm{p}<0.05)$ especially in $\mathrm{CMN} 5, \mathrm{NH}_{3}-\mathrm{N}$ levels in treatment groups decreased $(\mathrm{p}<0.05)$.

The day silage was uncovered ( 0 day), the number of enterobacter was found out to be $1.01 \log _{10} \mathrm{cfu} / \mathrm{g}$ at the CON group,

Table 2. The effects of different cumin essential oil levels on silage qualities $(n=3)$

\begin{tabular}{lccccccc}
\hline Treatments $^{1)}$ & Smell & Structure & Colours & DLG point & Quality & Flieg point & Quality \\
\hline CON & 8.0 & 4.0 & 1.0 & 13 & Moderate & 74.67 & Good \\
CMN3 & 8.0 & 4.0 & 1.0 & 13 & Moderate & 80.63 & Excellent \\
CMN5 & 8.0 & 4.0 & 1.0 & 13 & Moderate & 95.21 & Excellent \\
\hline
\end{tabular}

DLG, Deutsche Landwirtschafts-Gesellschaft.

1) CON, control; CMN3, cumin essential oil 300 mg/kg; CMN5, cumin essential oil 500 mg/kg.

Table 3. Chemical composition of fresh alfalfa and silage ensiled for 120 days (\% dry matter)

$\mathrm{OM}$, organic matter; $\mathrm{CP}$, crude protein; EE, ether extract; $C F$, crude fiber; NFE, nitrogen-free extract; $C A$, crude ash; NDF, neutral detergent fiber; $A D F$, acid detergent fiber; $A D L$, acid detergent lignin.

1)WA, wilting alfalfa; CON, control; CMN3, cumin essential oil 300 mg/kg; CMN5, cumin essential oil 500 mg/kg.

${ }^{a b c}$ Means with different letters in the same column are statistically significant $(p<0.05)$. 
Table 4. Fermentation quality of alfalfa silage ensiled for 120 days ${ }^{1)}$

\begin{tabular}{lcccccc}
\hline Treatments $^{2)}$ & DM (\%) & pH & WSC (g/kg DM) & LA (g/kg DM) & NH $_{3}-\mathbf{N}(\mathbf{g} / \mathbf{k g ~ T N})$ & WL (\%) \\
\hline CON & $32.50 \pm 0.41$ & $4.88 \pm 0.01^{\mathrm{a}}$ & $79.01 \pm 0.06^{\mathrm{a}}$ & $34.82 \pm 1.43^{\mathrm{c}}$ & $33.61 \pm 1.25^{\mathrm{a}}$ & $1.46 \pm 0.04^{\mathrm{a}}$ \\
CMN3 & $33.28 \pm 0.24$ & $4.77 \pm 0.02^{\mathrm{b}}$ & $46.01 \pm 0.02^{\mathrm{b}}$ & $44.57 \pm 0.29^{\mathrm{b}}$ & $14.50 \pm 0.27^{\mathrm{c}}$ & $1.33 \pm 0.00^{\mathrm{b}}$ \\
CMN5 & $32.44 \pm 0.02$ & $4.37 \pm 0.01^{\mathrm{c}}$ & $34.02 \pm 0.06^{\mathrm{c}}$ & $80.49 \pm 0.57^{\mathrm{a}}$ & $19.16 \pm 0.46^{\mathrm{b}}$ & $1.25 \pm 0.01^{\mathrm{c}}$ \\
p & 0.128 & 0.001 & 0.001 & 0.001 & 0.001 & 0.002 \\
\hline
\end{tabular}

DM, dry matter; WSC, water-soluble carbohydrates; $\mathrm{LA}$, lactic acid; $\mathrm{NH}_{3}-\mathrm{N}$, ammonia nitrogen; $\mathrm{WL}$, weight loss.

1) Wilted alfalfa contained 33.67\% DM, 6.0 pH, 84 WSC (g/kg DM), and 720 buffer capacity (Meq NaOH kg/DM).

2) CON, control; CMN3, cumin essential oil $300 \mathrm{mg} / \mathrm{kg}$; CMN5, cumin essential oil $500 \mathrm{mg} / \mathrm{kg}$.

abc Means with different letters in the same column are statistically significant $(p<0.05)$.

whereas it was too low to be determined in CMN3 and CMN5 groups $(\mathrm{p}<0.05)$. The level of mould was determined as 2.49 $\log _{10} \mathrm{cfu} / \mathrm{g}$ on the control group, while none were found in the treatment groups (Table 5). Cumin essential oil increased number of LAB according to the dose used $(\mathrm{p}<0.05)$ and decreased the number of yeast $(\mathrm{p}<0.05)$, however it did not completely prevent their development.

The results of the aerobic exposure test are given in Table
5. It was observed at the during of aerobic period $(3,5$, and 7 day) that there was an significant decreased amount of $\mathrm{CO}_{2}$, number of yeast and mould in treatments compared to $\mathrm{CON}$ $(p<0.05)$. It was found out that the addition of cumin essential oil prevented aerobic decomposition.

Adding cumin essential oil into the alfalfa silage increased ESOM amount (Table 6). The ME content all in groups calculated with the ESOM amounts were found to be higher than

Table 5. Effects of cumin essential oils on overall composition of alfalfa silages after 7 days of aerobic exposure and on microbial counts

\begin{tabular}{|c|c|c|c|c|c|c|c|}
\hline Items & Parameters ${ }^{1)}$ & Dry matter (\%) & $\mathrm{pH}$ & $\begin{array}{l}\text { Enterobacter } \\
\left(\log _{10} \mathrm{cfu} / \mathrm{g}\right)\end{array}$ & $\begin{array}{c}\text { Lactobacilli } \\
\text { (log cfu/g) }\end{array}$ & $\begin{array}{c}\text { Yeast } \\
\left(\log _{10} \mathrm{cfu} / \mathrm{g}\right)\end{array}$ & $\begin{array}{c}\text { Mould } \\
\left(\log _{10} \mathrm{cfu} / \mathrm{g}\right)\end{array}$ \\
\hline \multirow[t]{5}{*}{0 day } & CON & $32.50 \pm 0.41$ & $4.88 \pm 0.01^{a}$ & $1.01 \pm 0.48^{\mathrm{a}}$ & $3.51 \pm 0.02^{c}$ & $4.86 \pm 0.02^{\mathrm{a}}$ & $2.49 \pm 0.15^{\mathrm{a}}$ \\
\hline & CMN3 & $33.28 \pm 0.24$ & $4.77 \pm 0.02^{b}$ & 0 & $6.18 \pm 0.03^{b}$ & $3.43 \pm 0.03^{c}$ & $0.00 \pm 0.00^{b}$ \\
\hline & CMN5 & $32.44 \pm 0.02$ & $4.37 \pm 0.01^{c}$ & 0 & $7.31 \pm 0.01^{\mathrm{a}}$ & $3.76 \pm 0.14^{b}$ & $0.00 \pm 0.00^{b}$ \\
\hline & p & 0.128 & 0.001 & 0.001 & 0.001 & 0.001 & 0.001 \\
\hline & & & & & $\mathrm{CO}_{2}(\mathrm{~g} / \mathrm{kg} \mathrm{DM})$ & & \\
\hline \multirow[t]{4}{*}{3 day } & CON & $32.76 \pm 0.08$ & $5.55 \pm 0.08^{\mathrm{a}}$ & 0 & $11.44 \pm 0.06^{\mathrm{a}}$ & $7.27 \pm 0.13^{\mathrm{a}}$ & $5.26 \pm 0.02^{\mathrm{a}}$ \\
\hline & CMN3 & $33.60 \pm 0.05$ & $5.08 \pm 0.34^{\mathrm{ab}}$ & 0 & $5.76 \pm 0.06^{c}$ & $6.85 \pm 0.02^{b}$ & $3.54 \pm 0.08^{b}$ \\
\hline & CMN5 & $32.60 \pm 0.84$ & $4.88 \pm 0.01^{b}$ & 0 & $7.88 \pm 0.06^{b}$ & $7.03 \pm 0.17^{b}$ & $3.25 \pm 0.05^{c}$ \\
\hline & $p$ & 0.357 & 0.001 & - & 0.001 & 0.092 & 0.001 \\
\hline \multirow[t]{4}{*}{5 day } & CON & $32.59 \pm 0.03^{b}$ & $5.59 \pm 0.09^{\mathrm{a}}$ & 0 & $14.52 \pm 0.06^{\mathrm{a}}$ & $9.12 \pm 0.04^{\mathrm{a}}$ & $8.77 \pm 0.06^{\mathrm{a}}$ \\
\hline & CMN3 & $33.60 \pm 0.17^{a}$ & $5.41 \pm 0.01^{\mathrm{ab}}$ & 0 & $8.46 \pm 0.06^{c}$ & $8.87 \pm 0.02^{b}$ & $6.76 \pm 0.06^{b}$ \\
\hline & CMN5 & $32.19 \pm 0.20^{c}$ & $5.20 \pm 0.08^{b}$ & 0 & $11.86 \pm 0.07^{b}$ & $8.17 \pm 0.03^{c}$ & $6.33 \pm 0.04^{c}$ \\
\hline & $p$ & 0.001 & 0.011 & - & 0.001 & 0.001 & 0.001 \\
\hline \multirow[t]{4}{*}{7 day } & CON & $32.84 \pm 0.01$ & $8.79 \pm 0.01^{\mathrm{a}}$ & 0 & $15.01 \pm 0.06^{a}$ & $10.60 \pm 0.05^{a}$ & $10.20 \pm 0.03^{\mathrm{a}}$ \\
\hline & CMN3 & $33.18 \pm 0.24$ & $7.57 \pm 0.04^{b}$ & 0 & $12.34 \pm 0.25^{c}$ & $9.29 \pm 0.03^{b}$ & $8.12 \pm 0.03^{b}$ \\
\hline & CMN5 & $32.65 \pm 0.12$ & $7.04 \pm 0.02^{c}$ & 0 & $13.54 \pm 0.25^{b}$ & $9.45 \pm 0.08^{b}$ & $8.06 \pm 0.01^{b}$ \\
\hline & p & 0.125 & 0.001 & - & 0.001 & 0.001 & 0.001 \\
\hline
\end{tabular}

1) CON, control; CMN3, cumin essential oil $300 \mathrm{mg} / \mathrm{kg}$; CMN5, cumin essential oil $500 \mathrm{mg} / \mathrm{kg}$.

${ }^{a b c}$ Means with different letters in the same column are statistically significant $(p<0.05)$.

Table 6. ESOM and ME contents of alfalfa silages (kcal/kg DM)

\begin{tabular}{lcccccc}
\hline Treatments $^{1)}$ & ESOM (\% DM) & ME $_{\text {ESOM }}$ & ME $_{\text {OM }}$ & ME $_{\text {NDF }}$ & ME $_{\text {ADF }}{ }^{*}$ & ME $_{\text {ADL }}$ \\
\hline CON & $52.29 \pm 0.24^{\mathrm{c}}$ & $1,032 \pm 1.22^{\mathrm{b}}$ & $2,134 \pm 6.66^{\mathrm{c}}$ & $2,719 \pm 1.66^{\mathrm{c}}$ & $2,573 \pm 3.28^{\mathrm{b}}$ & $1,787 \pm 13.57^{\mathrm{c}}$ \\
CMN3 & $64.06 \pm 0.04^{\mathrm{a}}$ & $1,301 \pm 6.02^{\mathrm{a}}$ & $2,396 \pm 0.88^{\mathrm{a}}$ & $2,818 \pm 2.40^{\mathrm{a}}$ & $2,729 \pm 2.08^{\mathrm{a}}$ & $2,118 \pm 23.67^{\mathrm{a}}$ \\
CMN5 & $59.16 \pm 0.14^{\mathrm{b}}$ & $1,288 \pm 4.73^{\mathrm{a}}$ & $2,286 \pm 7.06^{\mathrm{b}}$ & $2,758 \pm 2.40^{\mathrm{b}}$ & $2,527 \pm 7.94^{\mathrm{c}}$ & $1,878 \pm 23.13^{\mathrm{b}}$ \\
p & 0.001 & 0.001 & 0.001 & 0.001 & 0.001 & 0.001 \\
\hline
\end{tabular}

ESOM, enzyme soluble organic matter; ME, metabolizable energy; DM, dry matter; OM, organic matter; NDF, neutral detergent fiber; ADF, acid detergent fiber; ADL, acid detergent lignin.

1) CON, control; CMN3, cumin essential oil $300 \mathrm{mg} / \mathrm{kg}$; CMN5, cumin essential oil $500 \mathrm{mg} / \mathrm{kg}$.

abc Means with different letters in the same column are statistically significant $(p<0.01)$.

* ME contents were translated into kilocalories. 
the CON group $(\mathrm{p}<0.05)$. The increase of $\mathrm{ME}$ contents determined through calculations with different regression equations, revealed that addition of cumin essential oil (expected CMN5, $\left.\mathrm{ME}_{\mathrm{ADF}}\right)$ affects the energy contents of silages positively.

The beginning material of silage, DDM, DMI, and RFV are given in Table 7. DDM values of alfalfa silages were determined as between $68.50 \%$ and $71.89 \%$. The level of DDM calculated through ADF contents (Table 3) of silages in CMN3 group increased with the decrease of ADF content, while decreased with the increase of ADF contents in CMN5 group. DMI was found out to be $3.62,4.26$, and 3.84 in CON, CMN3, and CMN5 respectively, and it was determined that DMI was higher in groups with cumin essential oil addition $(\mathrm{p}<0.05)$.

\section{DISCUSSION}

There are many ways that can used to improve the microbial flora during the ensiling process of alfalfa. In addition the carbohydrate resources [1] are used to increase the carbohydrate level through various inoculants or antimicrobial additives [20]. In recent years, consumer organizations suggest the use of natural products instead of chemical additives at livestock enterprises to improve feed quality and safety. Although physical scoring was above the findings of Çiftçi et al [1], and the Flieg's score was lower than that of Çiftçi et al [1].

Addition of oregano and cinnamon essential oils to field peas decreased the protein fractionation significantly after 60 day ensilage process [5]. In another study, addition of cinnamon leaf extract to barley silage at different quantities caused an increase at $\mathrm{CP}$ amount [3]. These results were found to be similar to the oregano and cinnamon essential oil of SoycanÖnenç et al [5], as well as to cinnamon extract of Chaves et al [3].

In this research, crude ash (CA) level at three groups was found to be higher than the determined amount at alfalfa silages in the researches of Lindgren et al [21]. Results obtained from studies revealing the crude ash content level at inoculant added silages [21] indicate that inoculant addition does not provide a significant decrease in the amount of CA. The reason

Table 7. Dry matter digestibility, dry matter intake and relative feed value of alfalfa silages

\begin{tabular}{lccc}
\hline Treatments $^{1)}$ & DDM (\%) & DMI (\%) & RFV \\
\hline WA & 66.3 & 3.12 & 160.31 \\
CON & $68.50 \pm 0.07^{\mathrm{b}}$ & $3.62 \pm 0.01^{\mathrm{c}}$ & $192.17 \pm 0.52^{\mathrm{c}}$ \\
CMN3 & $71.89 \pm 0.04^{\mathrm{a}}$ & $4.26 \pm 0.02^{\mathrm{a}}$ & $236.93 \pm 0.87^{\mathrm{a}}$ \\
CMN5 & $67.50 \pm 0.17^{\mathrm{c}}$ & $3.84 \pm 0.02^{\mathrm{b}}$ & $201.08 \pm 1.30^{\mathrm{b}}$ \\
p & 0.001 & 0.001 & 0.001 \\
\hline
\end{tabular}

DDM, digestible dry matter; DMI, dry matter intake; RFV, relative feed value.

1) WA, wilting alfalfa; CON, control; CMN3, cumin essential oil 300 mg/kg; CMN5, cumin essential oil $500 \mathrm{mg} / \mathrm{kg}$.

abc Means with different letters in the same column are statistically significant $(p<0.01)$. for different CA levels determined in silages is that products for silage include inorganic matter (soil, etc.) at different levels [22]. In this research, it is estimated that due to the control group being prepared last, it is possible that it includes more soil etc. and therefore it includes more crude ash content compared to cumin essential oil added groups. In this case, it is possible that the difference among OM value in groups is caused by crude ash content.

The addition of cumin essential oil was not effective on DM, and revealed no similarity with the findings of Soycan-Önenç et al [5]. While the findings of this study carried out through the addition of cumin essential oil, which has antimicrobial effect as in antibiotics, revealed $\mathrm{pH}$ level of 4.37 at CMN5 group similar to the findings of Kung et al [20], the $\mathrm{pH}$ levels of all the other groups were lower than the findings of Bolsen et al [23]. On the other hand, Soycan-Önenç et al [5] determined the $\mathrm{pH}$ level to be 4.4 and 4.47 on the 60th day through the addition of oregano and cinnamon essential oil to field peas. Cumin essential oil used in this study includes $44.47 \%$ cuminaldehyde, $12.12 \%$ carvacrol, and $8.82 \%$ paracymen as basic components. Cuminaldehyde and carvacrol have a selective antimicrobial effect [24], which decreased the number of detrimental microorganisms (yeast and mould), and increased the number of beneficial microorganisms (LAB). This situation explains the low $\mathrm{pH}$ levels determined at $\mathrm{CMN} 3$ and CMN5 groups. A low $\mathrm{pH}$ level in silages opens the epicyte fractions by increasing acid hydrolysis of hemicellulose [22] Sucrose is liberated during enzymatic cell wall hydrolysis and provides an additional substrate that LAB can use to produce LA.

While high level LA production causes $\mathrm{pH}$ level to decrease to 4.0, it also limits proteolytic activity [21]. It is possible that the decrease of contents in NDF, ADF, and ADL is due to the effect of $\mathrm{pH}$. Thus, the increase of ESOM in the same group also supports this situation. Besides, in the same group, the highest LAB level and correspondingly high LA level and low WSC level, as well as high level of CP and low amount of $\mathrm{NH}_{3}-\mathrm{N}$ support articles of Nadeau et al [25]. Soycan-Önenç et al [5] determined that LA content decreased in field peas silages opened on the 60th day after the addition of oregano, cinnamon, and oregano+cinnamon essential oils. However, in this study it was determined that there was an increase in LA contents. While oregano and cinnamon essential oils reveal a decreasing effect on LA amount through inhibiting LAB, cumin essential oil caused increase in LA amount by promoting LAB activity. The increase of LAB amount and the decrease in WSC in CMN3 and CMN5 groups also support this idea. WL decreased in groups with cumin essential oil, and the lowest level of WL was in CMN5. Thus, it can be interpreted that microorganisms which find sufficient amount of WSC in the environment develop better and provide high quality silage and decrease WL [26]. The addition of cumin essential 
oil to alfalfa silages promoted LAB production, and this effect became more evident depending on the increase of essential oil. Enterobacteria, Clostridia, Listeria and mould development in bunker and their metabolic activities greatly endangers silage hygiene [27]. While at the end of ensilage process, the level of enterobacter was found to be $1.01 \log _{10} \mathrm{cfu} / \mathrm{g}$ and the level of mould was determined as $2.49 \log _{10} \mathrm{cfu} / \mathrm{g}$ on the CON group, these organisms were not found in the treatment group. These findings can be associated with the effect of cumin essential oil on Enterobacteria and mould. Another opinion is that due to Listeria and Enterobacteria being more susceptible to acidity compared to Clostridia spores, when the bunker has an acidic environment, development of Listeria and Enterobacteria can be supressed at the beginning of fermentation [22].

Thus, cumin essential oil increased number of LAB according to the dose used. LAB transformed WSC to LA, and $\mathrm{pH}$ decreased depending on the increasing amount of LA. Development of enterobacter and mould was prevented at low level $\mathrm{pH}$. The addition of cumin essential oil to alfalfa silage decreased the number of yeast, however could not stop some development. Since there is no possibility of air entering the environment of silage during fermentation, it is thought that the yeast population determined in silages is the one present at the beginning material (wilting alfalfa).

Before being exposed to aerobic conditions, it is stated that population of yeast and mould, as well as WSC are positively related to LA and LAB [27]. The addition of cumin essential oil into alfalfa silage increased the aerobic stability. However, WSC contents being very high provide a resource for the development of yeast and mould. Therefore, cumin essential oil could not suppress the development of yeast and mould sufficiently. WSC contents were affected by withering. There are studies carried out to determine that the aerobic decomposition of silages increase according to their exposure to aerobic conditions [28].

The use of formic acid based preservative (FAB) in a research carried out by Filya et al [29], increased the degradability of DM and OM of corn silages. The antimicrobial property of FAB prevented the development of enterobacteria and clostridia spores, particularly yeast and mould, and this caused DM and OM degradability of silages to increase. Cumin essential oil used in this research revealed a similar effect with formic acid, thus increased the amount of OM dissolved in the enzyme significantly in comparison with the CON group $(\mathrm{p}<0.05)$.

The quality of forage is usually determined through the calculations of physical, chemical, and biological values of forages. RFV developed in the USA for alfalfa and other forages, is used widely to measure the feeding value of forages. In this method, for the calculation of RFV, values of NDF and ADF were used. At full bloom RFV is taken as 100 and the more this value decreases, the more the quality of forage decreases, while the increase of RFV shows that the quality of forage is increasing. The forage quality was lower when RFV decreased below 100, and was higher when RFV increased [30]. In this study, RFV was determined to be above 150, and revealed an increase depending on cumin essential oil addition. The decrease of cell wall components (NDF and ADL) that cause difficulties in the digestion in alfalfa silages affected the RFV positively. RFV determined in alfalfa silages, when compared to 100 points of alfalfa plant, it is approved to be a rough forage with highest quality. RFV of silages increased through the use of cumin essential oil, and the highest value was found out in CMN3 group.

\section{IMPLICATIONS}

Cumin essential oil used in this research improved fermentation, and affected chemical and microbiological characteristics of silages. Especially the addition of $300 \mathrm{mg} / \mathrm{kg}$ cumin provided cell wall fractionation through stimulating activities of enzymes that fractionate cell walls. It also increased the number and activity of LAB through providing a development of LAB. Correspondingly, the transformation of sugar into LA, and lactic acid present in the environment at high amount decreased the $\mathrm{pH}$ level, thus inhibited proteolytic enzymes that break down proteins and the transformation of proteins into ammonia decreased. In addition, it increased ESOM amount, and concordantly provided an increase of ME contents. Similarly, DMI and RFV ratio increased. After opening the silage, it kept its aerobic stability for three days.

\section{AUTHOR CONTRIBUTIONS}

AT: Did collected data and whrote paper, SSÖ: Designed the study, supported in providing literature, conducted the master of thesis and proofreading and corrected the article.

\section{CONFLICT OF INTEREST}

We certify that there is no conflict of interest with any financial organization regarding the material discussed in the manuscript.

\section{ACKNOWLEDGMENTS}

This study was funded by NKUBAP (University of Namık Kemal Scientific Research Project) within the framework of NKUBAP.00.24.YL.14.04. It was taken form MSc Thesis.

\section{REFERENCES}

1. Çiftçi M, Çerçi İH, Dalkılıç B, Güler T, Ertaş O. The investigation of possibility of apple as carbohydrate source in alfalfa silage. YYU Vet Fac J 2005;16:93-8. 
2. Kılıç A. Ensilage feed. İzmir, Turkey: Bilgehan Press; 1986.

3. Chaves AV, Baah J, Wang Y, McAllister TA, Benchaar C. Effects of cinnamon leaf, oregano and sweet orange essential oils on fermentation and aerobic stability of barley silage. J Sci Food Agric 2012;92:906-15.

4. Kung JL, Williams P, Schmidt RJ, Hu W. A Blend of essential plant oils used as an additive to alter silage fermentation or used as a feed additive for lactating dairy cows. J Dairy Sci 2008;91:4793-800.

5. Soycan-Önenç S, Fisun K, Coşkuntuna L, Özdüven ML, Gümüş T. The effect of oregano and cinnamon essential oils on fermentation quality and aerobic stability of field pea silages. AsianAustralas J Anim Sci 2015;28:1281-7.

6. Barker SB, Summerson WH. The colorimetric determination of lactic acid in biological material. J Biol Chem 1941;138:53554.

7. Playne MJ, Mc Donald P. The buffering constituent of herbage and of silage. J Sci Food Agric 1966;17:264-8.

8. Anonymous. The analysis of agricultural material. London, UK: Reference book; 1986. pp. 427-8.

9. Ashbell G, Weinberg ZG, Azrieli A, Henand Y, Horev B. A simple system study the aerobic deterioration of silages. Can Agric Engin 1991;33:391-3.

10. AOAC. Protein (crude) in animal feed combustion method 990. 03. In: “Official Methods of Analysis". First supplement (1990) to the15th ed. Arlington, VA, USA: AOAC International; 1990. p. 18-9.

11. Van Soest PJ, Robertson JB, Lewis BA. Method for dietary fiber, neutral detergent fiber and nostarch polysaccharides in relation to animal nutrition. J Dairy Sci 1991;74:3583-97.

12. Naumann C, Bassler R. Method book. B. III. The chemical analysis of feeds. Darmstadt, Germany: VDLUFA-Verlag; 1993.

13. Seale DR, Pahlow G, Spoelstra SF, et al. Methods for the microbiological analysis of silage. Uppsala, Sweden: Proceeding of The Eurobac Conference; 1990. p. 147.

14. Jeroch H, Drochner W, Simon O. Nutrition on farm livestock. Stuttgart, Germany: Verlag Eugen Ulmer; 1999. 525 p.

15. Anonymous. Animal feeds-determination of metabolizable energy (chemical method). Turkish Standards Institute (TSE); 1991. Publ. No. 9610. pp. 1-3.

16. Kirchgessner M, Kellner RJ, Roth FX, Ranfft K. For estimating the feed value using crude fiber and the cell wall fractions of the detergent analysis. Landwirtsch Forsch 1977;30:245-50.
17. Kirchgessner M, Kellner RJ. Estimation of the energetic feed value of green and chough feed through the cellulas method. Landwirtsch Forsch 1981;34:276-81.

18. Van Dyke NJ, Anderson PM. Interpreting a forage analysis. Alabama Cooperative Extension; 2000. Circular ANR-890.

19. Soysal MI. Principles of biometrinin (Statistics I ve II Lecture notes). Tekirdağ, Turkey: LB.64. Faculty of Acriculture University of Trakya; 1998.

20. Kung LJr, Tung RS, Maciorowski K. Effect of microbial inoculant (Ecosyl-TM) and/ or a glcopeptide antibiotic on fermantation and aerobic stability of wilted alfalfa silage. Anim Feed Sci Technol 1991;35:37-48.

21. Lindgren S, Lingvall P, Kaspersson A, Kartzow A, Rydberg E. Effect of inoculants grain and formic acid on silage fermentation. Swedish J Agric Res 1983;13:91-100.

22. Kurtoğlu V. Silage and silage additives. Konya, Turkey: Aybil Press; 2011.

23. Bolsen KK, Ashbell G, Weinberg ZG. Silage fermentation and silage additives. Asian-Australas J Anim Sci 1996;9:483-94.

24. Davidson PM, Naidu AS. 2000. Phyto-phenols. In: Naidu AS, editor. Natural food antimicrobial systems. Boca raton, FL, USA: CRC Press; 2000. pp. 265-94.

25. Nadeau EMG, Buxton DR, Russell JR, Allison MJ, Young JW. Enzyme, bacterial inoculant, and formic acid effects on silage composition of orchardgrass and alfalfa. J Dairy Sci 2000;83: 1487-502.

26. Henderson N. Silage additives. Anim Feed Sci Technol 1993; 45:35-56.

27. Weinberg ZG, Ashbell G, Hen Y, Azriell A. The effect of applying lactic acid bacteria at ensiling on the aerobic stability of silage. J Appl Bacteriol 1993;75:512-8.

28. Gonzalez G, Rodriguez AA. Effect of storage method on fermantation characteristics. Aerobic stability and forage intake of tropical grasses ensiled in round bales. J Dairy Sci 2003;86: 926-33.

29. Filya İ, Sucu E, Hanoğlu H. A research on the quality characteristics and nutritive value of small plastic bale maize silages ensiled with biological silage additives and their use in lamb fattening. AU Agric Facul J Agric Sci 2004;10:158-62.

30. Yavuz M. Determination of some ruminant feeds' relative feed value and in vitro digestion values. Univ Gaziosmanpaşa Fac Agric 2005;22:97-101. 